\title{
IDENTIFIKASI TINGKAT KERENTANAN AKUIFER TERHADAP PENCEMARAN DI KECAMATAN SUMOBITO KABUPATEN JOMBANG DENGAN MENGGUNAKAN METODE GOD
}

\author{
Hari Siswoyo ${ }^{1, *}$ \\ ${ }^{1}$ Jurusan Teknik Pengairan, Fakultas Teknik, Universitas Brawijaya, Malang, Jawa Timur 65145 \\ *email korespondensi: hari siswoyo@ub.ac.id
}

\begin{abstract}
ABSTRAK
Bahaya pencemaran terhadap potensi air tanah yang dimanfaatkan sebagai sumber air irigasi perlu diantisipasi agar tidak mengakibatkan degradasi kualitas air tanah. Langkah awal dalam tindakan antisipasi tersebut adalah dengan cara identifikasi tingkat kerentanan akuifer terhadap bahaya pencemaran. Identifikasi tingkat kerentanan akuifer terhadap pencemaran dapat dilakukan dengan menggunakan metode GOD berdasarkan jenis akuifer, litologi lapisan pembatas akuifer, dan kedalaman akuifer. Berdasarkan analisis dengan menggunakan metode GOD dapat dinyatakan bahwa di lokasi kajian tingkat kerentanan akuifer terkekang terhadap bahaya pencemaran dapat diabaikan dan tingkat kerentanan akuifer semi terkekang terhadap bahaya pencemaran adalah rendah.
\end{abstract}

Kata-kata kunci: akuifer; air tanah; kerentanan; metode GOD; pencemaran

\section{PENDAHULUAN}

Kecamatan Sumobito merupakan salah satu kecamatan di wilayah Kabupaten Jombang Provinsi Jawa Timur dengan luas $47,47 \mathrm{~km}^{2}$ dan terdiri dari 21 desa. Penggunaan lahan terluas di wilayah kecamatan tersebut adalah berupa sawah yang mencapai $67 \%$ dari total luas wilayah kecamatan. Hasil pertanian di daerah tersebut adalah padi, jagung, kedelai, dan tebu (Badan Pusat Statistik Kabupaten Jombang, 2017). Kecamatan Sumobito adalah salah satu daerah di Kabupaten Jombang yang mengalami surplus tinggi dalam produksi pangan dan dalam kategori kecamatan tahan pangan (Wulandari, 2016).

Keberhasilan pembangunan dalam bidang pertanian di Kecamatan Sumobito tidak terlepas dari keberadaan sistem irigasi yang baik. Selain dipasok oleh air permukaan, pada saat musim kemarau wilayah tersebut juga mendapat pasokan air irigasi dari air tanah melalui sumur-sumur produksi. Sumur-sumur produksi tersebut pada umumnya memanfaatkan potensi air tanah dalam pada akuifer terkekang dan akuifer semi terkekang. Untuk mengantisipasi terjadinya pencemaran air tanah akibat aktivitas domestik, pertanian, maupun industri, maka langkah awal yang perlu dilakukan adalah identifikasi tingkat kerentanan akuifer terhadap pencemaran. Hal ini diperlukan sebagai dasar dalam tindakan pencegahan terhadap terjadinya pencemaran air tanah.

Identifikasi tingkat kerentanan akuifer terhadap pencemaran dapat dilakukan dengan menggunakan Metode GOD. Metode GOD digunakan untuk menentukan nilai indeks GOD berdasarkan 3 paremeter yaitu jenis akuifer (Groundwater confinement), litologi lapisan pembatas atas akuifer (ㅁverlying strata), dan kedalaman muka air tanah untuk akuifer bebas atau kedalaman sampai dengan lapisan terdapatnya air tanah untuk akuifer terkekang atau semi terkekang (Depth to groundwater table or strike). Berdasarkan nilai indeks GOD dapat ditentukan tingkat kerentanan akuifer terhadap pencemaran. Metode ini memilki kesederhanaan dalam hal konsep dan apikasinya, dan telah diuji coba secara meluas untuk pengukuran kerentanan akuifer terhadap pencemaran di Amerika Latin dan Karibia selama tahun 1990-an (Foster et al., 2007). Metode ini telah digunakan dalam sejumlah penelitian oleh para peneliti terdahulu di berbagai negara untuk mengidentifikasi tingkat kerentanan akuifer (Fernandes et al., 2014; Gad et al., 2015; Hastuti dkk., 2016; Falowo et al., 2017; Knouz et al., 2017; Olojoku et al., 2017).

Tujuan kajian ini adalah untuk mengidentifikasi tingkat kerentanan akuifer (akuifer terkekang dan akuifer semi terkekang) terhadap pencemaran di lokasi kajian dengan menggunakan metode GOD. Hasil kajian ilmiah ini diharapkan dapat menjadi salah satu pedoman teknis dalam upaya menjaga kelestarian potensi air tanah di lokasi kajian sehingga dapat dimanfaatkan secara berkelanjutan sebagai sumber air irigasi. 


\section{METODE}

\section{Lokasi Kajian}

Lokasi kajian ilmiah ini adalah di Kecamatan Sumobito, Kabupaten Jombang, Provinsi Jawa Timur. Contoh yang digunakan dalam kajian ini adalah 20 sumur produksi pada akuifer terkekang dan akuifer semi terkekang dengan variasi kedalaman $50-123 \mathrm{~m}$ di bawah permukaan tanah yang tersebar di wilayah Kecamatan Sumobito. Peta lokasi kajian dan sebaran contoh ditunjukkan dalam Gambar 1 di bawah ini.

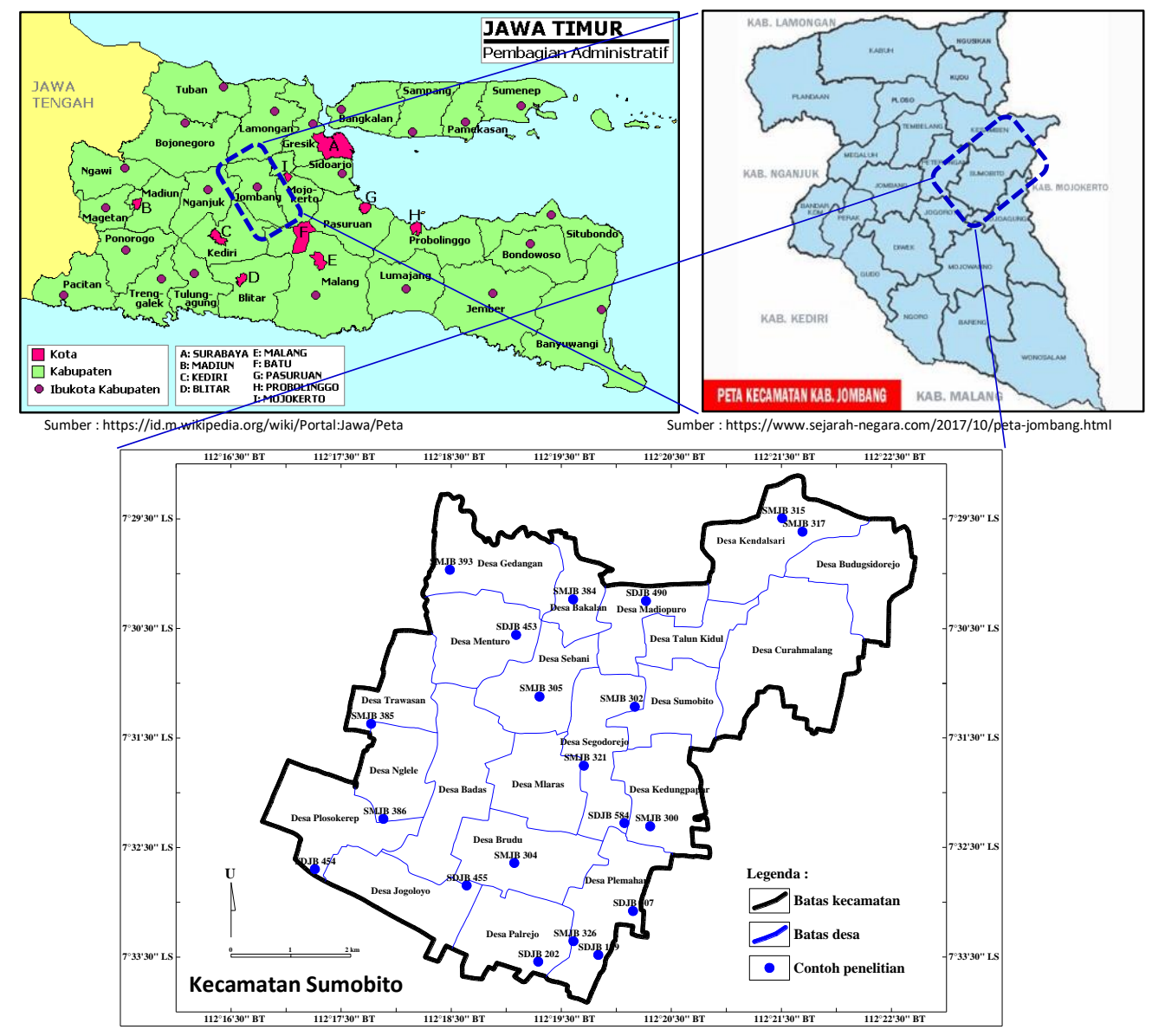

Gambar 1. Peta lokasi kajian dan sebaran contoh

\section{Alat dan Bahan}

Peralatan yang digunakan dalam kajian ini antara lain meliputi: Global Positioning System (GPS) merk Garmin 60 digunakan untuk menentukan koordinat lokasi contoh-contoh sumur produksi di lapangan. Bahan yang diperlukan di dalam kajian ini meliputi: peta rupabumi dan log litologi sumur produksi. Peta Rupabumi Indonesia skala 1:25.000 yang diterbitkan oleh Badan Koordinasi Survey dan Pemetaan Nasional sebanyak 4 lembar (1508-343 Mojoagung, 1508-344 Sooko, 1508-621 Kesamben, dan 1508-622 Mojokerto) digunakan sebagai peta dasar untuk menentukan batasan lokasi kajian, pengeplotan lokasi contoh sumur produksi, dan penggambaran peta sebaran tingkat kerentanan akuifer. Data log litologi sumur produksi (diperoleh dari Kegiatan Pendayagunaan Air Tanah BBWS Brantas) digunakan sebagai dasar untuk menentukan jenis akuifer, jenis formasi batuan (litologi), dan kedalaman akuifer di lokasi kajian.

\section{Prosedur Kerja}

Identifikasi tingkat kerentanan akuifer terhadap pencemaran di lokasi kajian dilakukan berdasarkan berdasarkan tahapan sebagai berikut (Foster et al., 2007):

1. Mengidentifikasi jenis akuifer (nilai indeks $\underline{\underline{G}}$ ), dengan nilai indeks $0,0-1,0$.

2. Mendeskripsikan lapisan yang berada di atas lapisan akuifer berdasarkan tingkat konsolidasi dan jenis litologi (nilai indeks $\underline{\boldsymbol{O}}$ ), dengan nilai indeks $0,4-1,0$. Parameter 0 yang mewakili kondisi litologi ditentukan secara tertimbang dari litologi yang berbeda. 
3. Mengestimasi kedalaman muka air tanah untuk akuifer bebas atau kedalaman akuifer teratas untuk akuifer terkekang dan semi terkekang (nilai indeks $\underline{D}$ ), dengan nilai indeks $0,6-1,0$.

Bagan sistem evaluasi kerentanan akuifer terhadap pencemaran dengan metode GOD seperti ditunjukkan dalam Gambar 2 di bawah ini.

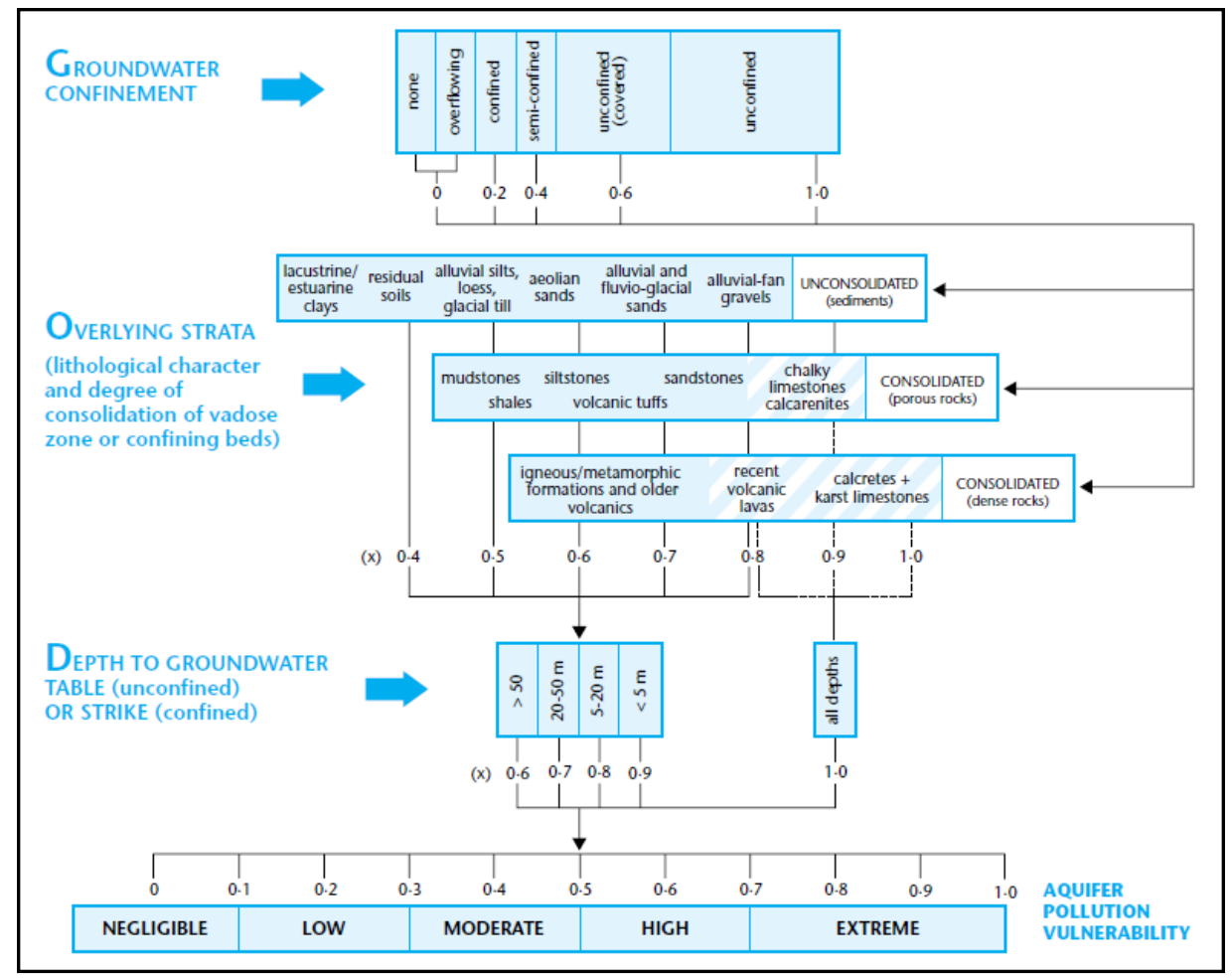

Gambar 2. Sistem GOD untuk evaluasi kerentanan akuifer terhadap pencemaran (Foster et al., 2007)

Nilai indeks GOD merupakan perkalian antara nilai indeks $G$, nilai indeks $O$, dan nilai indeks $D$. Interpretasi tingkat kerentanan air tanah dilakukan berdasarkan nilai indeks GOD seperti ditunjukkan dalam Tabel 1 di bawah ini.

Tabel 1. Tingkat kerentanan air tanah berdasarkan indeks GOD (Foster et al., 2007)

\begin{tabular}{ccl}
\hline Indeks GOD & Tingkat kerentanan & \multicolumn{1}{c}{ Definisi } \\
\hline $0,7-1,0$ & Ekstrim & $\begin{array}{l}\text { Rentan terhadap sebagian besar pencemar air dengan dampak } \\
\text { cepat dalam berbagai skenario pencemaran }\end{array}$ \\
\hline $0,5-0,7$ & Tinggi & $\begin{array}{l}\text { Rentan terhadap banyak pencemar dalam banyak skenario } \\
\text { pencemaran }\end{array}$ \\
\hline $0,3-0,5$ & Sedang & $\begin{array}{l}\text { Rentan terhadap beberapa polutan tetapi hanya ketika dibuang } \\
\text { secara terus menerus }\end{array}$ \\
\hline $0,1-0,3$ & Rendah & $\begin{array}{l}\text { Hanya rentan terhadap pencemar konservatif dalam jangka panjang } \\
\text { ketika dibuang secara meluas dan terus menerus }\end{array}$ \\
\hline $0,0-0,1$ & Dapat diabaikan & $\begin{array}{l}\text { Terbatas pada tempat tanpa aliran air tanah vertikal (kebocoran) } \\
\text { yang signifikan }\end{array}$ \\
\hline
\end{tabular}

Pemetaan sebaran spasial nilai indeks kerentanan air tanah di lokasi kajian dilakukan dengan cara menginterpolasi data koordinat lokasi titik contoh yang dipetakan dan nilai indeks yang dipetakan dari tiap titik contoh yang tidak beraturan ke dalam grid dengan jarak teratur. Pembuatan grid dilakukan dengan menggunakan Metode Kriging untuk mengestimasi besarnya nilai yang mewakili suatu titik tidak tersampel berdasarkan titik-titik tersampel yang berada di sekitarnya dengan mempertimbangkan korelasi spasial yang ada dalam data tersebut (Awali dkk., 2013; Golden Software Inc., 2002).

\section{HASIL DAN DISKUSI}

Identifikasi keterdapatan air tanah dilakukan terhadap akuifer terkekang dan akuifer semi terkekang. Akuifer terkekang memiliki lapisan pembatas atas dan bawah berupa akuiklud, sedangkan 
akuifer semi terkekang memiliki lapisan pembatas atas berupa akuitar. Akuiklud merupakan suatu lapisan, formasi, atau kelompok formasi satuan geologi yang kedap air dengan nilai konduktivitas hidraulik yang sangat kecil sehingga tidak memungkinkan air melewatinya. Akuitar adalah suatu lapisan, formasi, atau kelompok formasi satuan geologi yang kedap air dengan nilai konduktivitas hidraulik yang kecil namun masih memungkinkan air melewati lapisan ini walaupun dengan gerakan yang lambat (Kodoatie, 1996). Lapisan yang dapat diidentifikasikan sebagai akuiklud adalah lempung sampai dengan lanau (Sosrodarsono dan Takeda, 1987), sedangkan untuk lanau sampai dengan pasir halus merupakan lapisan akuitar (Kodoatie, 2012).

Berdasarkan hasil analisis dengan menggunakan metode GOD terhadap contoh log litologi sumur produksi, didapatkan nilai indeks GOD untuk akuifer terkekang berkisar 0,077 - 0,098 dengan tingkat kerentanan dapat diabaikan $(<0,1)$ dan untuk akuifer semi terkekang berkisar 0,186-0,216 dengan tingkat kerentanan rendah $(0,1-0,3)$. Nilai indeks GOD dan tingkat kerentanan akuifer di lokasi kajian seperti ditunjukkan dalam Tabel 2 di bawah ini.

Tabel 2. Tingkat kerentanan akuifer di lokasi kajian

\begin{tabular}{|c|c|c|c|c|c|c|c|}
\hline \multirow[t]{2}{*}{ No. } & \multirow[t]{2}{*}{ Nama Sumur } & \multirow[t]{2}{*}{ Desa } & \multirow[t]{2}{*}{ Koordinat Lokasi } & \multicolumn{2}{|c|}{ Akuifer Terkekang } & \multicolumn{2}{|c|}{ Akuifer Semi Terkekang } \\
\hline & & & & Indeks GOD & Tingkat Kerentanan & Indeks GOD & Tingkat Kerentanan \\
\hline 1 & SDJB 584 & Segodorejo & $7^{\circ} 32^{\prime} 14,2^{\prime \prime}$ LS; $112^{\circ} 20^{\prime} 06,4^{\prime \prime}$ BT & 0,093 & Dapat diabaikan & --- & --- \\
\hline 2 & SDJB 199 & Plemahan & $7^{\circ} 33^{\prime} 26,9^{\prime \prime}$ LS; $112^{\circ} 19^{\prime} 52,1^{\prime \prime}$ BT & 0,090 & Dapat diabaikan & --- & --- \\
\hline 3 & SDJB 202 & Palrejo & $7^{\circ} 33^{\prime} 30,6^{\prime \prime}$ LS; $112^{\circ} 19^{\prime} 19,2^{\prime \prime}$ BT & 0,079 & Dapat diabaikan & --- & --- \\
\hline 4 & SDJB 453 & Menturo & $7^{\circ} 30^{\prime} 30,5^{\prime \prime}$ LS; $112^{\circ} 19^{\prime} 07,1^{\prime \prime}$ BT & 0,085 & Dapat diabaikan & --- & --- \\
\hline 5 & SDJB 454 & Plosokerep & $7^{\circ} 32^{\prime} 39,6^{\prime \prime}$ LS; $112^{\circ} 17^{\prime} 16,9^{\prime \prime}$ BT & 0,079 & Dapat diabaikan & --- & --- \\
\hline 6 & SDJB 455 & Brudu & $7^{\circ} 32^{\prime} 48,6^{\prime \prime}$ LS; $112^{\circ} 18^{\prime} 40,0^{\prime \prime}$ BT & 0,097 & Dapat diabaikan & --- & --- \\
\hline 7 & SDJB 490 & Madiopuro & $7^{\circ} 30^{\prime} 11,8^{\prime \prime}$ LS; $112^{\circ} 20^{\prime} 18,2^{\prime \prime}$ BT & 0,089 & Dapat diabaikan & --- & --- \\
\hline 8 & SDJB 507 & Plemahan & $7^{\circ} 33^{\prime} 02,7^{\prime \prime}$ LS; $112^{\circ} 20^{\prime} 11,1^{\prime \prime}$ BT & 0,098 & Dapat diabaikan & --- & --- \\
\hline 9 & SMJB 300 & Kedungpapar & $7^{\circ} 32^{\prime} 16,0^{\prime \prime}$ LS; $112^{\circ} 20^{\prime} 20,5^{\prime \prime}$ BT & 0,078 & Dapat diabaikan & 0,186 & Rendah \\
\hline 10 & SMJB 302 & Segodorejo & $7^{\circ} 31^{\prime} 10,1^{\prime \prime}$ LS; $112^{\circ} 20^{\prime} 12,1^{\prime \prime}$ BT & 0,095 & Dapat diabaikan & 0,206 & Rendah \\
\hline 11 & SMJB 304 & Brudu & $7^{\circ} 32^{\prime} 36,2^{\prime \prime}$ LS; $112^{\circ} 19^{\prime} 06,1^{\prime \prime}$ BT & 0,093 & Dapat diabaikan & --- & --- \\
\hline 12 & SMJB 305 & Sebani & $7^{\circ} 31^{\prime} 04,5^{\prime \prime}$ LS; $112^{\circ} 19^{\prime} 19,9^{\prime \prime}$ BT & --- & --- & --- & --- \\
\hline 13 & SMJB 315 & Kendalsari & $7^{\circ} 29^{\prime} 26,2^{\prime \prime}$ LS; $112^{\circ} 21^{\prime} 32,8^{\prime \prime}$ BT & 0,091 & Dapat diabaikan & --- & --- \\
\hline 14 & SMJB 317 & Kendalsari & $7^{\circ} 29^{\prime} 33,6^{\prime \prime}$ LS; $112^{\circ} 21^{\prime} 43,9^{\prime \prime}$ BT & 0,092 & Dapat diabaikan & 0,196 & Rendah \\
\hline 15 & SMJB 321 & Segodorejo & $7^{\circ} 31^{\prime} 42,6^{\prime \prime}$ LS; $112^{\circ} 19^{\prime} 44,2^{\prime \prime}$ BT & --- & --- & 0,204 & Rendah \\
\hline 16 & SMJB 326 & Plemahan & $7^{\circ} 33^{\prime} 19,3^{\prime \prime}$ LS; $112^{\circ} 19^{\prime} 38,5^{\prime \prime}$ BT & --- & --- & 0,192 & Rendah \\
\hline 17 & SMJB 384 & Bakalan & $7^{\circ} 30^{\prime} 10,9^{\prime \prime}$ LS; $112^{\circ} 19^{\prime} 38,3^{\prime \prime}$ BT & 0,093 & Dapat diabaikan & --- & --- \\
\hline 18 & SMJB 385 & Trawasan & $7^{\circ} 31^{\prime} 19,5^{\prime \prime}$ LS; $112^{\circ} 17^{\prime} 47,7^{\prime \prime}$ BT & 0,079 & Dapat diabaikan & --- & --- \\
\hline 19 & SMJB 386 & Nglele & $7^{\circ} 32^{\prime} 11,9^{\prime \prime}$ LS; $112^{\circ} 17^{\prime} 54,4^{\prime \prime}$ BT & 0,096 & Dapat diabaikan & 0,216 & Rendah \\
\hline 20 & SMJB 393 & Gedangan & $7^{\circ} 29^{\prime} 54,6^{\prime \prime}$ LS; $112^{\circ} 18^{\prime} 30,8^{\prime \prime}$ BT & 0,077 & Dapat diabaikan & --- & --- \\
\hline
\end{tabular}

Tingkat kerentanan terhadap pencemaran bagi akuifer terkekang di lokasi kajian dapat diabaikan (nilai indeks GOD $<0,1$ ), sedangkan akuifer semi terkekang memiliki tingkat kerentanan yang rendah (nilai indeks GOD 0,1-0,3). Tingkat kerentanan akuifer terkekang diidentifikasi berdasarkan keberadaan akuifer terkekang teratas dari 17 contoh sumur produksi. Sementara itu, untuk tingkat kerentanan akuifer semi terkekang diidentifikasi berdasarkan sumur-sumur produksi yang memanfaatkan potensi air tanah dari akuifer semi terkekang (SMJB 321 dan SMJB 326) dan keberadaan akuifer semi terkekang di atas akuifer terkekang seperti pada sumur produksi SMJB 300, SMJB 302, SMJB 317, dan SMJB 386. Contoh sumur SMJB 305 tidak diidentifikasi tingkat kerentanannya karena keberadaan potensi air tanah yang dimanfaatkan tidak memenuhi definisi akuifer terkekang maupun semi terkekang. Keberadaan akuiklud yang merupakan batas akuifer terkekang pada sumur tersebut berada di kedalaman $60 \mathrm{~m}$ yaitu pada dasar sumur produksi (kedalaman $61 \mathrm{~m}$ ).

Tingkat kerentanan akuifer terkekang terhadap pencemaran di lokasi kajian dapat diabaikan karena akuifer tersebut memiliki batas atas lapisan kedap air (impermeable layer). Keberadaan lapisan kedap air atau disebut juga akuiklud dengan kelulusan air mendekati nol membuat aliran air tanah tidak dapat menembus lapisan tersebut (Kodoatie, 1996) sehingga pencemar sulit untuk menembus masuk ke dalam akuifer terkekang. Sementara itu, untuk akuifer semi terkekang yang memiliki batas atas berupa akuitar dengan kelulusan air yang kecil (Kodoatie, 1996) juga membuat pencemar sulit untuk menembus ke dalam akuifer semi terkekang sehingga memiliki tingkat kerentanan yang rendah. Namun demikian, kelas kerentanan akuifer yang dapat dibaikan masih tetap harus diwaspadai apabila ada aliran air tanah vertikal (kebocoran) yang signifikan pada lapisan pembatas. Untuk kelas kerentanan yang rendah, juga memiliki 
kemungkinan tercemar terhadap pencemar konservatif dalam jangka panjang ketika dibuang secara meluas dan terus menerus (Foster et al., 2007).

Hasil yang didapatkan dalam kajian ini dimana secara umum akuifer terkekang memiliki tingkat kerentanan yang dapat diabaikan dan akuifer semi terkekang memiliki tingkat kerentanan yang rendah sejalan dengan hasil-hasil penelitian sebelumnya. Hastuti dkk. (2016) menganalisis kerentanan air tanah terhadap pencemaran di dataran alluvial Kota Semarang pada akuifer bebas dan semi terkekang. Berdasarkan hasil analisis tersebut dinyatakan bahwa pada akuifer bebas memiliki tingkat kerentanan sedang sampai dengan tinggi, sedangkan pada akuifer semi terkekang memiliki tingkat kerentanan rendah. Olojoku et al. (2017) mengidentifikasi tingkat kerentanan akuifer bebas pada daerah pedesaan di Northcentral Nigeria, dimana tingkat kerentanan akuifer di daerah tersebut berkisar 0,49-0,56 dengan mayoritas (95\%) tingkat kerentanan akuifernya tinggi. Tingkat kerentanan akuifer yang tinggi pada umumnya pada daerah-daerah dengan jenis akuifer bebas atau memiliki muka air tanah yang dangkal (Fernandes et al., 2014; Falowo et al., 2017; Knouz et al., 2017). Secara umum dapat dinyatakan bahwa sumber daya air tanah yang berada pada akuifer terkekang maupun akuifer semi terkekang lebih aman terhadap potensi bahaya pencemaran. Sebaran tingkat kerentanan akuifer di lokasi kajian ditunjukkan dalam Gambar 3.

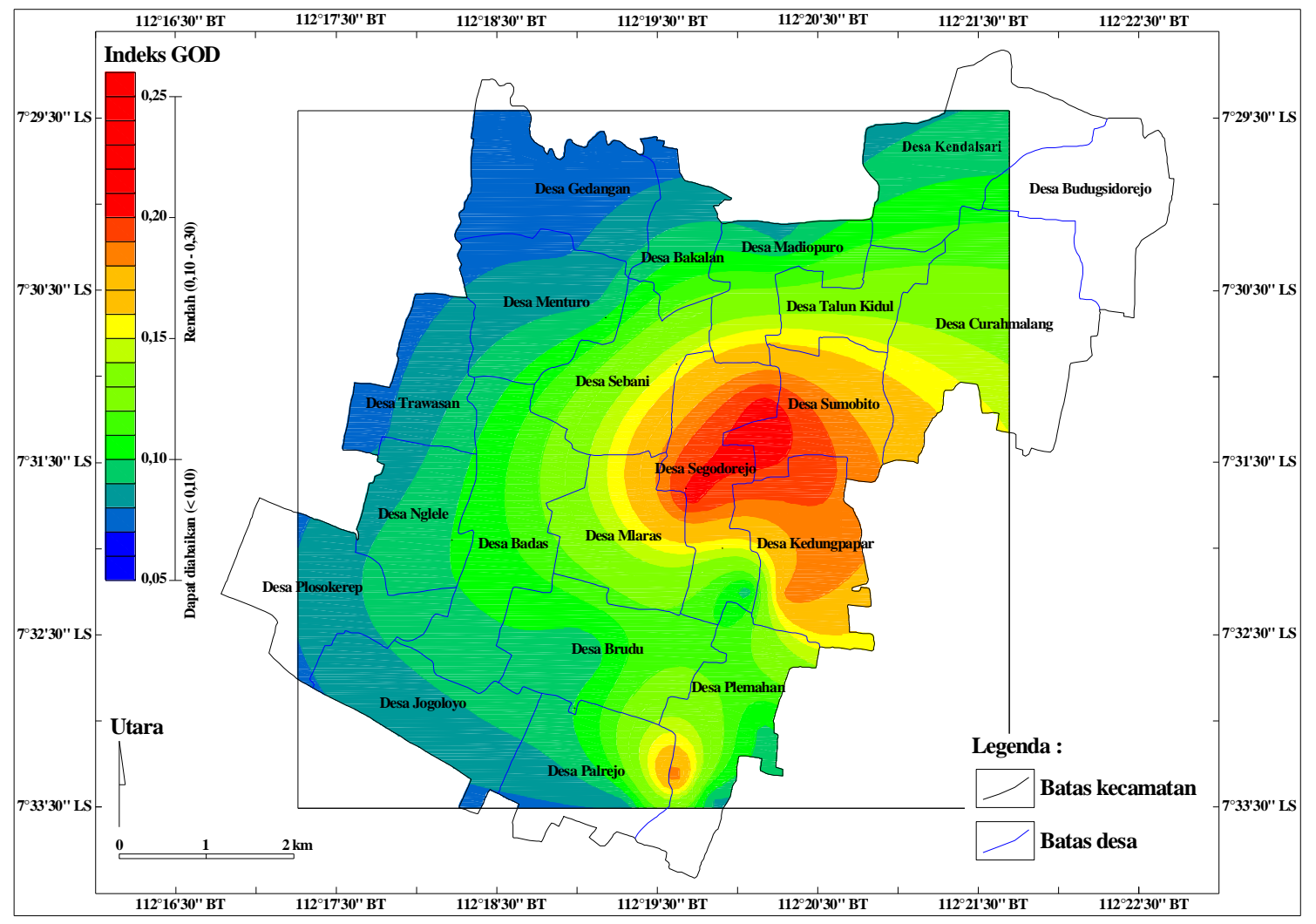

Gambar 3. Sebaran tingkat kerentanan akuifer di lokasi kajian

\section{KESIMPULAN}

Berdasarkan hasil evaluasi tingkat kerentanan akuifer terhadap pencemaran di lokasi kajian menggunakan metode GOD, dapat disimpulkan bahwa nilai indeks GOD untuk akuifer terkekang adalah $<0,1$ dan nilai indeks GOD untuk akuifer semi terkekang berkisar 0,1-0,3. Tingkat kerentanan terhadap pencemaran untuk akuifer terkekang dapat diabaikan sedangkan untuk akuifer semi terkekang memiliki tingkat kerentanan yang rendah. Untuk mencegah terjadinya pencemaran air tanah pada akuifer semi terkekang di lokasi kajian, maka disarankan agar tidak dilakukan pembuangan limbah yang dapat mengakibatkan pencemaran air tanah.

\section{DAFTAR PUSTAKA}

Awali, A.A., Yasin, H., dan Rahmawati, R. 2013. Estimasi Kandungan Hasil Tambang Menggunakan Ordinary Indicator Kriging. Jurnal Gaussian, 2(1): 1-10. 
Badan Pusat Statistik Kabupaten Jombang. 2017. Kecamatan Sumobito Dalam Angka 2017. Jombang: Badan Pusat Statistik Kabupaten Jombang.

Falowo, O.O., Akindureni, Y., and Ojo, O. 2017. Groundwater Assessment and Its Intrinsic Vulnerability Studies Using Aquifer Vulnerability Index and GOD Methods. International Journal of Energy and Environmental Science, 2(5): 103-116. doi: 10.11648/j.ijees.20170205.13

Fernandes, L.F.S., Cardoso, L.V.R.Q., Pacheco, F.A.L., Leitão, S., and Moura, J.P. 2014. DRASTIC and GOD vulnerability maps of the Cabril River Basin, Portugal. Revista Escola de Minas, 67(2): 133-142.

Foster, S., Hirata, R., Gomes, D., D’Elia, M., and Paris, M. 2007. Groundwater Quality Protection, $2^{\text {nd }}$ printing. Washington, D.C.: The World Bank. ISBN 0-8213-4951-1.

Gad, M.I., El-Kammar, M.M., and Ismail, H.M.G. 2015. Groundwater Vulnerability Assessment Using Different Overlay and Index Methods for Quaternary Aquifer of Wadi El-Tumilat, East Delta, Egypt. Asian Review of Environmental and Earth Sciences, 2(1): 9-22.

Golden Software, Inc. 2002. Surfer-User's Guide, Contouring and 3D Surface Mapping for Scientists and Engineers. Colorado: Golden Software, Inc.

Hastuti, D., Yulianto, T., dan Putranto, T.T. 2016. Analisis Kerentanan Airtanah terhadap Pencemaran di Dataran Alluvial Kota Semarang Menggunakan Metode GOD dengan Memanfaatkan Data Resistivitas dan Data Hidrogeologi. Youngster Physics Journal, 5(4): 277-290.

Knouz, N., Bachaoui, E., and Boudhar, A. 2017. Cartography of intrinsic aquifer vulnerability to pollution using GOD method: Case study Beni Amir groundwater, Tadla, Morocco. Journal of Materials and Environmental Sciences, 8(3): 1046-1053.

Kodoatie, R.J. 1996. Pengantar Hidrogeologi. Yogyakarta: Andi.

Kodoatie, R.J. 2012. Tata Ruang Air Tanah. Yogyakarta: Andi.

Olojoku, I.K., Modreck, G., Adeyinka, O.S., and Adebayo, Y.M. 2017. Vulnerability Assessment of Shallow Aquifer Hand-Dug Wells in Rural Parts of Northcentral Nigeria using AVI and GOD Methods. The Pacific Journal of Science and Technology, 18(1): 325-333.

Sosrodarsono, S. dan Takeda, K. 1987. Hidrologi untuk Pengairan, Cetakan keenam. Jakarta: PT. Pradnya Paramita.

Wulandari, M. 2016. Analisis Tingkat Ketahanan Pangan Terhadap Kerawanan Pangan di Kabupaten Jombang Tahun 2015. Publikasi Ilmiah, Sumber: http://eprints.ums.ac.id/47093/24/NASKAH\%20PUBLIKASI-MEI.pdf [30 Maret 2018] 